\title{
Comparison of Serum Interleukin 10 Levels between Leprosy and Non-Leprosy Population
}

\author{
Perbandingan Kadar Interleukin 10 pada Penderita Kusta bukan Penderita Kusta \\ Adika Kodrati ${ }^{1}$, Eddy Mart Salim ${ }^{1}$, Zen Hafy ${ }^{1}$ \\ ${ }^{1}$ Faculty of Medicinem, Sriwijaya University, Palembang
}

DATA OF ARTICLE:

Received: 22 April 2019

Reviewed: 19 Jun 2019

Revised: 13 April 2020

Accepted: 12 Feb 2021

*CORRESPONDENCE:

dikafauzi4284@gmail.com

DOI:

10.18196/mmjkk.v21i1.6514

TYPE OF ARTICLE:

Research

\begin{abstract}
Leprosy is a chronic granulomatous infectious disease that attacks the peripheral nerves, skin, and other organs. The cytokine IL-10 can deactivate macrophages, inhibit IL-12 production, which also inhibits IFN- $\Upsilon$ production. IL10 directly inhibits CD4+T cells and antigen-presenting cell (APC) function in cells infected with M. leprae. The purpose of this study was to determine the differences in IL-10 levels in leprosy patients and non-patients at dr. Mohammad Hoesin Palembang Hospital. This study used a case-control design for comparing 2 groups. Respondents in this study were 80 people. The case samples were all leprosy patients who were treated at the dr. Mohammad Hoesin Hospital, Palembang for the period of January 16 - February 16, 2019, while the control group was medical personnel and paramedics who worked at the same hospital. The examination was carried out using the ELISA Sandwich method. The results showed that there was a significant difference in IL-10 levels between leprosy patients and non-leprosy leprosy $(p=0.000)$. The average IL-10 level in leprosy patients $(13.24 \mathrm{pg} / \mathrm{ml})$ was lower than that in non-patients $(40.15 \mathrm{pg} / \mathrm{ml})$. It is concluded that there is a difference in IL-10 levels between leprosy patients and non-leprosy patients in leprosy sufferers are lower than non-leprosy persons.
\end{abstract}

Keywords: leprosy; interleukin 10 (IL-10)

Abstrak: Kusta merupakan penyakit infeksi granulomatosa kronis yang menyerang saraf tepi, kulit dan organ lain. Sitokin IL-10 memiliki kemampuan menonaktifkan makrofag, menghambat produksi IL-17 dan IFN-Y. IL-10 berfungsi menghambat CD4 + sel T, fungsi antigen presenting cells (APC) dalam sel yang terinfeksi M. leprae. Tujuan penelitian mengetahui perbedaan kadar IL-10 penderita kusta dan bukan penderita di RSUP $d r$. Mohammad Hoesin Palembang. Penelitian ini menggunakan desain case control untuk membandingkan 2 kelompok. Responden penelitian sebanyak 80 orang. Sampel adalah semua penderita kusta yang berobat di RSUP dr Mohammad Hoesin Palembang periode 16 Januari-16 Febuari 2019, sedangkan kelompok kontrol adalah tenaga medis dan paramedis di RSUP dr. Mohammad Hoesin Palembang. Pemeriksaan menggunakan metode ELISA Sandwich. Hasil menunjukkan ada perbedaan signifikan kadar IL-10 penderita kusta dan bukan penderita kusta ( $p=0.000)$. Rata-rata kadar IL-10 pada penderita kusta (13.24 $\mathrm{pg} / \mathrm{ml})$ lebih rendah dibandingkan dengan bukan penderita $(40,15 \mathrm{pg} / \mathrm{ml})$. Disimpulkan terdapat perbedaan kadar IL-10 antara penderita kusta dengan penderita bukan penderita kusta, yaitu pada penderita kusta lebih rendah dibandingkan bukan penderita kusta.

Kata Kunci: kusta; interleukin, interleukin 10 


\section{INTRODUCTION}

Morbus Hansen (Leprosy) is a chronic infection that attacks the peripheral nerves, skin and other organs. ${ }^{1}$ This disease, if not treated promptly, can also trigger psychosocial disorders due to negative stigma developed in the community. The causative agent of leprosyis spread through droplets. ${ }^{2}$

The etiology of leprosy, the Mycobacterium leprae, is an acid-resistant, gram-positive, rod-shaped, obligate-aerobic bacteria which cannot be cultured on artificial intra cellular media. This microorganism was first discovered by Gerhard Armauer Hansen in 1873. ${ }^{3}$

According to WHO data (2016), leprosy cases have increased from 211.973 in 2015 to 214.783 in 2016. As many as $94 \%$ of leprosy cases reported in only 14 countries with $>1000$ new cases annually. Southeast Asia is the region with the third highest leprosy burden in the world in 2015 with a total of 156.118 cases. In Indonesia, leprosy cases were reported to be 17.025 and 17.202 in 2014 and 2015, respectively.

Interleukin 10 (IL-10) is a cytokine that has an opposite role to IL-17. ${ }^{4}$ These cytokines have the ability to deactivate macrophages, inhibit IL-12 as well as IFN-Y production. In addition, IL-10 directly inhibits CD4+ T cells and antigen presenting cells (APC) function in the M. leprae-infected cells. ${ }^{5}$ In lepromatous leprosy, TH2 Treg lymphocytes participate in the anti-inflammatory response and produce a number of cytokines, including IL 10, which inhibit macrophage activation and facilitate the survival of M. leprae.

According to Ministry of Health data in 2012, categorization of leprosy types is divided based on the Ridley Jopling and WHO classification system. ${ }^{6}$ Ridley and Jopling divided leprosy into several types, namely tuberculoid type (TT), borderline tuberculoid type (BT), mid-borderline type (BB), borderline lepromatous type (BL), and lepromatous type (LL). ${ }^{7}$ Meanwhile, the WHO classification system simplified this categorization into paucibacillary (PB) and multibacillary (MB) type. ${ }^{8}$ The statement also provided similar statement leprosy is classified according to $\mathrm{WHO}$ and Ridley-Jopling classification system . ${ }^{1} \mathrm{~A}$ study conducted at Kriplani Sucheta Hospital, showed that IL-10 levels among leprosy patients were higher $(59.48 \mathrm{pg} / \mathrm{ml})$ compared to the control group $(15.90 \mathrm{pg} / \mathrm{ml}){ }^{9}$ A similar statement was also expressed, where IL-10 levels in leprosy patients were significantly higher (median of $10 \mathrm{pg} / \mathrm{ml}$ ) compared to healthy controls (median of $2.5 \mathrm{pg} / \mathrm{ml}$ ) with $(\mathrm{p}<0.001) .{ }^{10} \mathrm{~A}$ study entitled "Correlation of Interlukin10 Levels with Bacterial Index in Leprosy Patients who Have Received Multidrug Therapy (MDT) Treatment performed demonstrated that IL-10 levels were significantly higher among patients diagnosed with MB leprosy (median of $17.5 \mathrm{pg} / \mathrm{ml}$ ) compared with PB leprosy (median of $13.3 \mathrm{pg} / \mathrm{ml}$ ). ${ }^{11}$

The purpose of this study was to investigate the difference in serum IL-10 levels between leprosy and healthy population. Individuals who met the inclusion criteria for both case and control groups were recruited consecutively.

\section{MATERIAL AND METHODS}

This observational analytical study was performed using a case-control design which compared the cases group with its matched control group. Blood samples were collected from all participants for laboratory assessment. This study included leprosy patients who visited Dermatovenereology Clinic of dr. Mohammad Hoesin Hospital Palembang and healthy medical personnel and families as the case and the control group, respectively. All the participants who met the inclusion criteria were recruited in a consecutive manner. The study was carried out for two months between January-February 2019. The minimum sample size was 80 subjects.

Mann Whitney $U$ test was performed as bivariate analysis to determine the difference between dependent and independent variables with the measurement scale being the ordinal and nominal difference test. 
This study was conducted at a government hospital, after obtaining a research permit from the Department of Research and Development of related institutions from January 16 to February 16, 2019. The minimum 80 samples were achieved by the end of the study period.

All patients who met the inclusion criteria underwent comprehensive clinical interview and provided their written informed consent that has previously been approved by Ethics Committee of Sriwijaya University with reference no. 298/ kepkrsmhfkunsri/2018 prior participation in this study. All participants who met the eligibility criteria underwent blood sample collection procedure for further IL10 levels examination.

The serum was derived from blood taken from the cubital vein using a disposable 3-cc syringe. The blood sample was then put in a red-capped vacutainer tube and was left at room temperature for \pm 10 minutes. Then the blood sample was transferred to the Biomolecular Laboratory of Sriwijaya University. Immediately following clot formation, the blood sample was centrifuged at $2000 \mathrm{rpm}$ for 5 minutes. Then the plasma was transferred to an Eppendorf tube (RNA Nuclease Free). The plasma was stored at -200C, until the required number of samples was obtained, IL-10 examination was carried out using the ELISA Sandwich method at the Biomolecular Laboratory of Sriwijaya University.

\section{RESULTS}

\section{Bivariate Analysis}

A bivariate analysis was performed to determine the difference in serum IL-10 levels between the case and the control group. For this regard, independent student $T$ test or Mann Whitney $U$ test was performed accordingly.

\section{Characteristics of the Study Population}

The data showed that the mean age of leprosy and healthy subjects was 35 and 36.5 years, respectively. Among leprosy patients, the proportion of males $(n=27)$ was slightly higher than women $(n=24)$. In details of the characteristic of respondents can be seen in Table 1.

Table 1. Characteristics of the Study Population

\begin{tabular}{|c|c|c|c|}
\hline Characteristics & $\begin{array}{c}\text { Leprosy Group } \\
(40)\end{array}$ & $\begin{array}{c}\text { Control Group } \\
(40)\end{array}$ & $P$-value \\
\hline \multicolumn{4}{|l|}{ Age } \\
\hline Mean (years) & 35 & 36.5 & $0.584^{*}$ \\
\hline \multicolumn{4}{|l|}{ Age group } \\
\hline $18-40$ & 24 & 26 & \multirow{3}{*}{0.890 ** } \\
\hline $40-60$ & 14 & 12 & \\
\hline$>60$ & 2 & 2 & \\
\hline \multicolumn{4}{|l|}{ Sex } \\
\hline Male & 27 & 16 & \multirow[t]{2}{*}{$0.014^{* *}$} \\
\hline Female & 13 & 24 & \\
\hline \multicolumn{4}{|l|}{ Ethnicity } \\
\hline Malay & 32 & 19 & \multirow{5}{*}{$0.029^{* * *}$} \\
\hline Bataknese & 1 & 2 & \\
\hline Javanese & 6 & 15 & \\
\hline Bugis & 0 & 2 & \\
\hline Chinese & 1 & 2 & \\
\hline \multicolumn{4}{|l|}{ Education } \\
\hline Uneducated & 0 & 1 & \multirow{4}{*}{$0.001^{* * *}$} \\
\hline Primary school & 12 & 6 & \\
\hline Middle school & 3 & 3 & \\
\hline High school & 21 & 8 & \\
\hline
\end{tabular}


College

Undergraduate school

2

Post-graduate school

Post-graduate schoo

\section{Occupation}

Unemployed

Teacher

Employee

Housewife

Farmer

Driver

Laborer

Physician

Paramedic

Duration of illness

0.5 years

6- 10 years

$>10$ years

4

1

Duration of MDT course

No treatment 2

PB 0 - 6 months 3

$\mathrm{PB}>6$ months 0

MB 0 - 12 months 19

MB> 12 months 9

ROM 7

= Independent T Test

** $=$ Pearson Chi Square Test

$* * *=$ Kolmogrov Smirnov Test

Table 2. Comparison in Serum IL-10 Levels between Leprosy and Control Group

\begin{tabular}{ccccc}
\hline Study Group & Median & Min & Max & P-value \\
\hline Leprosy & 13.24 & 5.59 & 19.41 & \\
Non-leprosy & & & & $0.000 *$ \\
& 40.15 & 29.41 & 44.71 & \\
\hline$=$ Mann Whitney U test & & & &
\end{tabular}

Table 2 shows that to determine the difference in IL-10 levels between leprosy patients and healthy controls, the Man Whitney test was performed. Table 2 shows that p-value of 0.000 indicating a significant difference in IL-10 levels between leprosy and control group.

The difference in IL-10 levels in leprosy and control groups also demonstrated on the Figure 10. That serum IL-10 levels were lower in leprosy patients $(13.24 \mathrm{pg} / \mathrm{ml})$ compared non leprosy $(40.15 \mathrm{pg} / \mathrm{ml})$. 


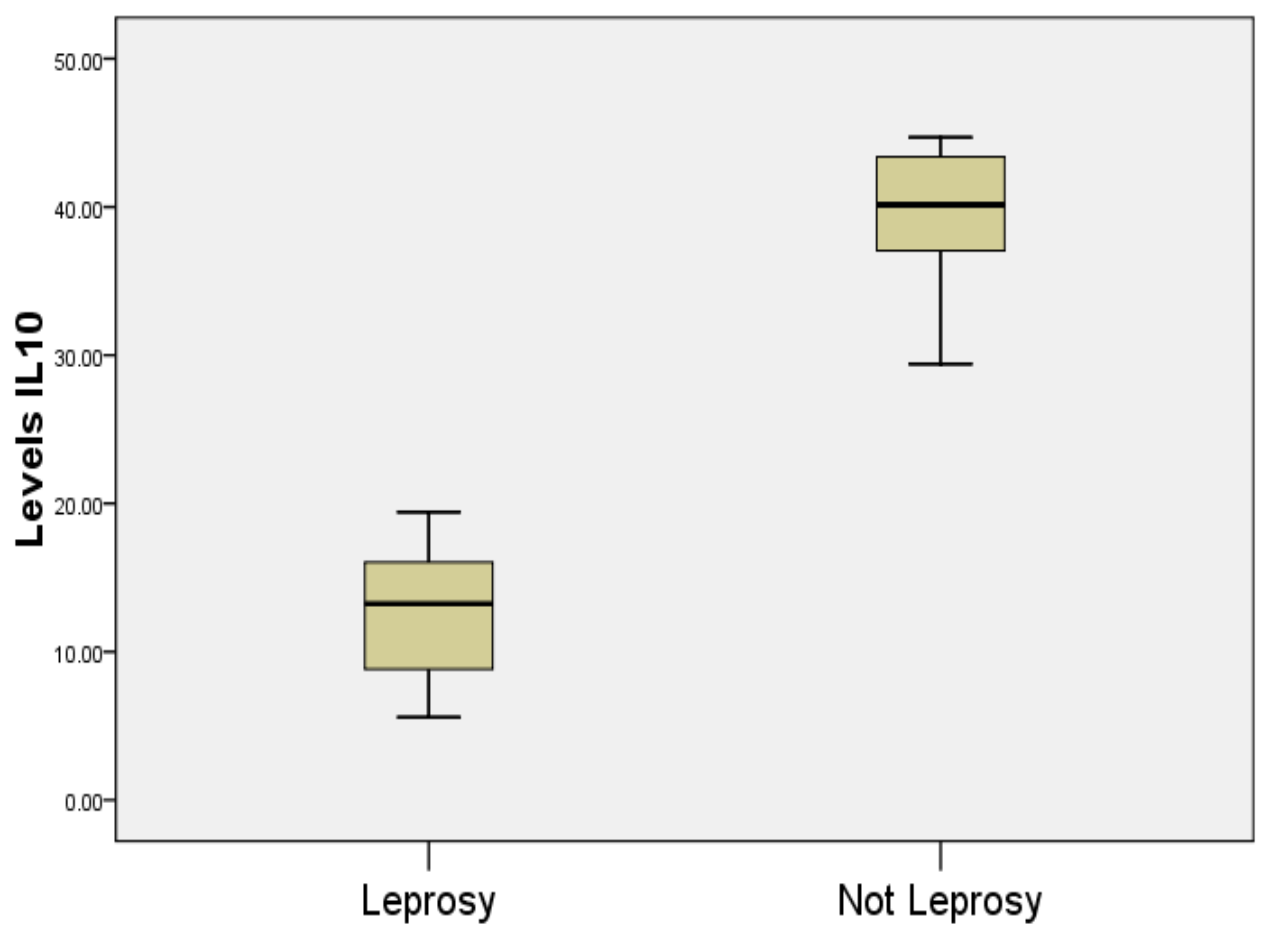

Respondent Status

Figure 10. Serum IL-10 levels among leprosy and healthy subject

\section{DISCUSSION}

The results of this case-control study showed that serum IL-10 levels were lower in the case group $(13.24 \mathrm{pg} / \mathrm{ml})$ compared to the control group $(40.15 \mathrm{pg} / \mathrm{ml})$. Administration of multi drug therapy (MDT) could result in suppression of bacterial index as well as reduced stimulation of specific immune response resulting in reduction of cytokines (including IL-10) production among people with leprosy. This theory is supported by the evidence demonstrating that patients with higher bacterial index show higher IL-10 levels.

The research in 1998 also provided supporting evidence showing a positive correlation between IL10 and the bacterial index. ${ }^{12}$ The study at 2011 showed that, among patients receiving MDT, M. leprae will be eradicated within several months in certain types of leprosy. ${ }^{13}$

This study showed contradictive results from the previous studies showing that IL-10 levels were higher among leprosy patients. The research by Madan et al in $2011^{9}$ who previously conducted similar study at Kriplani Sucheta Hospital showed that IL-10 levels were found to be higher $(59.48 \mathrm{pg} / \mathrm{ml})$ among leprosy patients compared to healthy controls $(15.90 \mathrm{pg} / \mathrm{ml})$.

Same with research conducted by Zenha and his collage which states that there is a decrease in bacterial index in leprosy patients who have received MDT therapy for $12-24$ months. ${ }^{14}$ The study conducted by Negera (2018) ${ }^{15}$ stated that the use of prednisolone in people with leprosy who experienced a reaction could reduce the antibody to M. leprae. In this case, pprednisolones treatment after 1 month decreased productivity from IL-10. 


\section{CONCLUSION}

It was concluded that IL-10 in leprosy patients was significantly lower than IL-10 in non-leprosy patients.

\section{REFERENCES}

1. Lee DJ, Rea TH, Modlin RL. Leprosy. In: Wolff K, Goldsmith LA, Katz SI, Gilchrest BA, Paller AS, Leffell DJ. 2012. Editors. Fitzpatrick's Dermatology in General Medicine. 8th ed. New York: Mc Graw Hill companies. 2012. 2253-63.

2. Sehgal VN, Joginder, Slit-skin smear in leprosy. Int J Dermatol 1990; 29 (1): p. 9-16.

3. Sandle T. Global Strategies for Elimination of Leprosy: A Review of Current Progress. J Anc Dis Prev Rem 2013.1: e112. Volume 1 • Issue 4 • 1000e112J Anc Dis Prev RemISSN:2329-8731 JADPR, an open access journal.

4. Bertholet S, Home DJ, Laughlin EM, Savlov M, Tucakovic I, Coler RN,et al, Effect of cemotherapy on whole blood cytokine responses Mycobacterium Tuberculosis antigen in a small cohort of patient with pulmonary tuberculosis. Clinical and Vaccine Immunology. 2011; 18 (8):1378-86

5. Emizola Fitri, Sugiri Yani Jane, Sartono Teguh Rahayu. Kadar Interleukin-10 dan Interleukin-17 selama 6 bulan terapi antituberkulosis Paru serta hubungan dengan keberhasilan terapi. 2015, Jurnal Respir Vol.35:1.

6. Kementerian Kesehatan RI Direktorat JenderalPengendalian Penyakit Dan Penyehatan Lingkungan. 2012. Pedoman Nasional Program Pengendalian Penyakit Kusta.

7. Jopling W.H. 2011. Hand Book of Leprosy.5 th ed New Delhi:CBS. Published \& Distributor. p.1-53, 92 100.

8. World Health Organization. Leprocy Update 2015: Time for action, accountabilityand Inclusionno. 35. 2016. p. 405-420. Apps. who.int/iris/bitsream/10665/249601/1/WER9135.pdf.

9. Madan, NK, Agarwal, KL., Chander, R., 2011, Serum Cytokine Profile In Leprosy And Its Correlation With Clinico-Histopathological Profile, Lepr Rev (2011) 82, 371-382

10. Attia EAS, Abdallah B, Khateeb E, Saad AA, Lotfi RA, Abdallah, Shennawy DE. Serum Th17 cytokines in leprosy:correlation with circulating CD4+CD25highFoxP3+ T-regs cells, as well asdown regulatory cytokine., Arch Dermatol Res. 2014. 306:793-801, DOI 10.1007/s00403-014-1486-2

11. Eva Krisna Sutedja, Jono Hadi Agusni, Hartati Purbo Dharmadji. Korelasi Kadar Interlukin-10 dengan Indeks Bakteri pada Pasien Kusta yang Telah Mendapat Pengobatan Multidrug Therapy (MDT). 2016. Vol 28

12. Moubasher MD, Kamel NA, Zedan Hatem, and Raheem DEA. Cytokines in leprosy II. Effect of treatment on serum cytokines in leprosy. Internasional Journal of Dermatology. 1998

13. Tomioka H. Immunology of leprosy-roles of cytokines in host defense against leprosy bacilli. In: Makino M, Matsuoka M, Goto M, Hatano K, editors. Leprosy science working toward dignity. 1st ed.Kanagawa: Tokai University. 2011. p. 72-87.

14. Zenha EMR, Ferreira MAN, Foss NT. Use of anti -PGL-1 antibodies to monitor therapy regimes in leprosy patients, Braz J Med Res. 2009: 42 (10): p. 968-972.

15. Negera E, Tilahun M, Bobosha K, Lambert SM, Walker SL, Spencer SJ., et al. (2018) The effects of prednisolone treatment on serological responses and lipid profiles in Ethiopian leprosy patients with Erythema Nodosum Leprosum reactions; Published: December 28, 2018. 